\title{
Chapter 13 \\ Circular Economy and the Policy Landscape in the UK
}

Julie Hill

\begin{abstract}
This chapter sets out the European policy origins of 'circular economy' thinking in the UK and discusses the extent to which the waste prevention plans written by the four countries of the UK (to fulfill the EU requirement) start to move the UK in the direction of more circular approaches. This is important for an understanding of what has driven UK action on this agenda. I argue that the "circular economy' has become an increasingly vigorous topic of debate in the UK. This has been manifested mainly through interest and use of the language by leading companies, but more recently also through political interest in Scotland and Wales, resulting in diverging policies in the countries of the UK. Heightened political interest in some parts of the UK has coincided with uncertainty about activity in the European Commission. The chapter discusses some of the difficulties in turning the concept into policy prescriptions.
\end{abstract}

Keywords Circular economy $\bullet$ Waste prevention $\bullet$ Resource efficiency $\bullet$ Resource security $\bullet$ Resilience

\section{Introduction}

The circular economy debate in the UK has evolved over the last 3-4 decades from a number of converging strands of thinking and activity, with their origins chiefly in Europe (Hill 2014). European Commission policy development on waste has been one of the key strands. Academic institutions and think tanks, with support from some leading businesses, have built on the foundations provided by European policy to raise awareness of the circular economy concept, but translating the aspirations into more progressive policies is a mixed picture among the four countries comprising the UK.

\footnotetext{
J. Hill ( $ه)$

Senior Visiting Fellow, Centre for Environmental Strategy, University of Surrey and Associate of Green Alliance, 36, Buckingham Palace Road, SW1W 0RE London, UK e-mail: jhill@green-alliance.org.uk
} 
What links the various strands of 'circular economy' discourse in the UK is 'systems thinking' - that keeping resources in productive use is not just a matter for individual firms on the one hand, or consumers on the other, but part of the whole economic system. This holistic view distinguishes these initiatives from much of waste management policy in the UK through the 1980s, 1990s and early twenty-first century, which has taken a predominantly 'end of pipe' view of the problems of waste. It is also a step on from political discourse concerning 'resource efficiency', which has often focused on industrial process efficiency rather than the whole life cycle of products, and is often unspecific as to which resources it is considering and what kind of efficiencies count most.

\section{The European Union's Development of Waste Policy and Resource Efficiency Initiatives}

European policy and legislation provides the overarching framework for the development of circular economy thinking in Europe and the UK. Without the development of legislation to limit landfill, reduce carbon emissions, improve recycling of key materials, introduce producer responsibility for end of life products, restrict toxic substances in the environment, influence the design of products, develop 'integrated product policy' and, crucially, sign up leading businesses to the ambition of greater resource efficiency, circular economy thinking would have far less traction. These actions have themselves been influenced by the more environmentally progressive European nations, in particular the Netherlands, Germany, Denmark and Sweden. The EU-promulgated notion of the 'waste hierarchy' is an important precursor to the ideas set out by many of those espousing the circular economy. The waste hierarchy has legal force through the Waste Framework Directive (EC 2008) and indicates the order of preference for waste options: prevention before reuse, reuse before recycling, recycling before energy recovery and lastly disposal. The circular economy approach can be seen as a more systematic (rather than incremental and material-based) application of this thinking.

The requirement of the 2008 Waste Framework Directive, for all member states to produce Waste Prevention Programmes by the end of 2013 (EC 2008), forced the issue further and gave policy makers an opportunity to set out circular economy ambitions. Much of the thinking behind this requirement had been done through the Commission's development of 'Integrated Product Policy (IPP)' - a series of initiatives starting in 2003 to understand which products accounted for the greatest environmental impact. Work under the IPP banner promoted 'life-cycle thinking' and advanced policy instruments, including the Ecodesign of Energy Using Products Directive, which aims to reduce the impact of products (EC 2014b).

Integrated Product Policy also underlies another relevant development - the process begun by the publication of the Roadmap to a Resource Efficient Europe championed by Environment Commissioner Janez Potocnik, and adopted by the full 
Commission in September 2011 (EC 2011b). The Resource Efficiency Roadmap is part of the Resource Efficiency Flagship of the Europe 2020 Strategy, which the European Commission describes as 'the European Union's growth strategy for the next decade and aimed at establishing a smart, sustainable and inclusive economy with high levels of employment, productivity and social cohesion' (EC 2011a).

The roadmap can be seen as a move to advance from the position reached by virtue of decades of waste legislation, and guide member states and businesses towards a consolidated and comprehensive vision of a resource efficient, circular economy. The roadmap does not place any legal obligations on member states, but it does set a number of benchmarks and milestones (notional targets), and has an ambition (vigorously debated) to agree indicators to measure resource efficiency. It has also given rise to the European Resource Efficiency Platform (EREP), a multistakeholder group of influential politicians, business people, NGOs and academics (EREP 2013). In addition, Horizon 2020, which is the EU's framework programme for research and innovation, is beginning to feature 'Circular Economy' and 'Industrial Symbiosis' as recognized terms, while OECD has started to refer to 'Industrial Ecology'.

A parallel initiative has been the development of the EU Raw Materials Initiative (EC 2014a), which has examined the future prospects for the availability of raw materials crucial to the economies of the EU. Fourteen materials, mainly metals, have been identified as critical and recommendations have been developed to secure future supplies. These recommendations fall into three categories, or 'pillars': (1) ensuring a 'level playing field' for access to resources in third countries (often referred to as 'resource diplomacy'); (2) securing supplies within Europe, such as reopening historic mines; and (3) improving resource efficiency and recycling, not least by highlighting how poor our current recovery of key metals is at present. It is the third 'pillar' that has contributed to the growing circular economy debate.

In 2014, in an attempt to consolidate and extend the progress made to date, Environment Commissioner Janez Potocnik proposed a Circular Economy package of new policy initiatives. This appeared at the very end of the 2010-2014 Commission in July 2014 (EC 2014c). Its principle measures were:

- A target of $70 \%$ recycling for municipal waste by 2030

- A target of $80 \%$ recycling of packaging waste by 2030

- Landfill bans from 2025 for plastics, metals, glass, paper, card and biodegradable waste.

The policy package also included two non-binding targets: the Commission wanted member states to adopt national strategies to reduce food waste by $30 \%$ by 2025 and proposed a target of a $30 \%$ increase in EU resource productivity by 2030 .

The package was greeted with disappointment from environmental groups who wanted more measures to stimulate activities such as re-use and remanufacturing (the 'inner' or 'tighter' loops, as described by the Ellen MacArthur Foundation) (EMF 2013). However, it was not welcomed by some key member states and leading business groups who felt that the $70 \%$ target was unachievable, and that the resource productivity target was not implementable, given the absence of good 
baseline data on which to assess progress against the target. The package did not survive the formation of the new Commission and was formally withdrawn in February 2015, as part of a drive to cut 'red tape' (Euroactive 2015). At the same time, the EU Commission pledged to propose a 'new and more ambitious' package by the end of 2015 . The uncertainty thus generated has been widely criticized by NGOs and some businesses.

\section{UK Policy Responses to Circular Economy Objectives}

Businesses are ahead of the policy debate on circular economy in the UK, in terms of their promulgation of the ideas and their understanding of the opportunities and barriers. This is evidenced by think tank/business partnerships such as the Ellen Macarthur Foundation (EMF 2013), the RSA's Great Recovery Project (RSA 2013) and the Green Alliance's Circular Economy Task Force (2015).

In the UK, the last decade of policy developments in Europe have worked through into policy into four main ways:

- Efforts to implement the $50 \%$ recycling target.

- Efforts to divert waste from landfill into recycling and energy from waste, particularly biodegradable wastes.

- The implementation of producer responsibility schemes for packaging, end of life vehicles, electronics and batteries.

- Discussions in the four countries comprising the UK of how to move to the 'inner loops' of re-use and remanufacturing, as well as greater product longevity.

The first three have been relatively successful, but focus on the lower parts of the waste hierarchy or the 'outer loops' of the circular economy. The last has been most evident in (1) the publication of a Resource Security Action Plan jointly by the UK Departments for Environment and for Business, and (2) the development of 'Waste Prevention Plans' by the four countries of the UK.

\section{The Resource Security Action Plan}

The UK's Resource Security Action Plan (RSAP) (Defra 2012) was a joint initiative of the UK Department for Environment, Food and Rural Affairs (Defra) and the Department for Business Innovation and Skills (BIS) to examine strategies for addressing resource security in the UK. The RSAP put more emphasis on recovery (i.e. circular approaches) than on opening up new sources of materials as a means to provide greater resource security. It also encouraged the environmental think tank Green Alliance to establish the Circular Economy Task Force as a means of engaging businesses in the solutions. The task force's first report, Resource Resilient UK, was published in July 2013 (Benton and Hazel 2013) and provided a new account of material 
security, as related to the environmental impacts and reputational threats of raw materials as much as to access. It also made recommendations for how UK policy could support the development of more circular approaches in pursuit of greater resource security. The report was well received by Government Ministers and by businesses.

\section{Waste Prevention Plans}

The Article 29 requirement of the revised EU Waste Framework Directive (2008/98/EC) that every member state should produce a Waste Prevention Programme by the end of 2013 provided a vehicle for countries that were so minded to produce something close to circular economy plans. Of the UK's devolved administrations, the most engagement has been seen in Scotland and Wales, with Zero Waste initiatives in Scotland developing rapidly before and during the independence referendum debates in 2014.

Looking at the Waste Prevention Programmes and the targets (Table 13.1) of the four countries of the UK side by side, some observations can be made:

Table 13.1 Waste prevention targets set by the four countries of the UK

\begin{tabular}{|c|c|}
\hline Country and document & Waste prevention targets \\
\hline $\begin{array}{l}\text { 'Safeguarding Scotland's Resources: } \\
\text { Blueprint for a more resource efficient } \\
\text { and circular economy' (Scottish } \\
\text { Government 2013) }\end{array}$ & $\begin{array}{l}\text { Reduce Scotland's waste by } 7 \% \text { by } 2017 \text { from } \\
2011 \text { levels and achieve a } 15 \% \text { reduction by } 2025\end{array}$ \\
\hline \multirow[t]{4}{*}{$\begin{array}{l}\text { 'Towards Zero Waste: One Wales, One } \\
\text { Planet' (Welsh Government 2013) }\end{array}$} & $\begin{array}{l}\text { Overall goal of achieving zero (non-recyclable) } \\
\text { waste by } 2050 \text { ( } 67 \% \text { less than } 2007 \text { levels) and an } \\
\text { interim goal of } 27 \% \text { less by } 2025\end{array}$ \\
\hline & $\begin{array}{l}\text { For household waste, a reduction of } 1.2 \% \text { every } \\
\text { year to } 2050 \text { based on } 2006 / 7 \text { baseline }\end{array}$ \\
\hline & $\begin{array}{l}\text { A general reduction of } 1.4 \% \text { every year to } 2050 \\
\text { based on } 2006 / 7 \text { baseline for industrial waste, with } \\
\text { specific targets for individual priority sectors: } \\
\text { metals, paper, chemicals and food }\end{array}$ \\
\hline & $\begin{array}{l}\text { A reduction of } 1.2 \% \text { every year to } 2050 \text { based on } \\
2006 / 7 \text { baseline for commercial waste }\end{array}$ \\
\hline \multirow{2}{*}{$\begin{array}{l}\text { 'Prevention is better than cure: the role of } \\
\text { waste prevention in moving to a more } \\
\text { resource efficiency economy' HM } \\
\text { Government } 2013 \text { (but only covers } \\
\text { England). (HMG 2013) }\end{array}$} & No national waste prevention target \\
\hline & $\begin{array}{l}\text { The Greening Government Commitment aims, by } \\
2015 \text {, to deliver a reduction in the amount of waste } \\
\text { generated from the Government Estate by } 25 \% \\
\text { from a } 2009 / 10 \text { baseline and ensure redundant ICT } \\
\text { equipment is reused or responsibly recycled }\end{array}$ \\
\hline $\begin{array}{l}\text { 'The Road to Zero Waste' (The waste } \\
\text { prevention programme for Northern } \\
\text { Ireland 2014) (DOENI 2014) }\end{array}$ & No targets proposed \\
\hline
\end{tabular}


- The economic advantages of waste prevention and circular economy are emphasised far more strongly by the Scottish and Welsh than by England and Northern Ireland.

- Resource security forms a central part of the rationale for waste prevention in all the plans.

- There is a strong emphasis on business taking up the challenge itself, rather than waiting for further policy initiatives, particularly from England and Northern Ireland.

- There is little money available from government to facilitate action.

- The Scottish and Welsh have set waste reduction targets (additionally to recycling targets), although the actions suggested are not explicitly linked to progress towards the targets.

- Targets are for waste reduction, rather than for the value to be recouped through circular economy approaches.

Other than the targets, when scrutinised in detail, the proposed actions of the four countries of the UK are not greatly divergent, but there are significant differences in language and tone. The Scottish Plan is most firmly aligned with the language of the circular economy, has strong political backing for the idea and has some of the most practical actions. These include the establishment of the Scottish Institute of Remanufacture at Strathclyde University, and the Resource Efficient Scotland service, which integrates advice to businesses on water, energy and materials, the first of its kind in the UK. Scottish Government is also considering Resource Utilisation Assessments which could develop into 'mass balance' exercises (helping businesses to understand inputs, outputs and consequent resource efficiency). Scotland has the advantage of building on legislation put in place in 2012, to require sorting of recyclable wastes by businesses. This was designed to create more certainty around supply of recyclates which, in turn, is hoped will generate demand for secondary materials, and there is a target $70 \%$ recycling and maximum $5 \%$ to landfill by 2025 for all Scotland's waste.

A test of the economic policy relevance is that circular economy is part of Scottish Enterprise's business strategy. The Scottish Government also sponsored a 2015 report by Green Alliance in partnership with the Scottish Council for Development and Industry detailing circular economy opportunities for three key sectors - Oil and Gas, Food and Drink, and Finance (Benton 2015), demonstrating the extent to which circular economy is seen as potential contributor to growth.

In Wales, the circular economy is tied up with a political commitment to future generations in a way that is probably unique in the world. The Welsh goal of 'One Planet Living' drives intervention and the key metric is ecological footprint reduction (NAWRS 2011). Separate recovery of materials from source is considered the best way to reduce the footprint (particularly the carbon component): this differs from the preference of many local authorities in England to collect recyclables together, or 'co-mingled'. To foster re-use, electronics are being kept whole wherever possible through source segregation. 
As well as the waste reduction targets, Welsh measures also promote source segregation of materials for recycling, and there is a target of $70 \%$ recycling of municipal waste by 2025. The existing Sustainable Development Duty is being given greater force through the forthcoming Environment Bill, with a requirement to make it an 'organising principle' which is given force through reporting requirements. All these measures are felt to contribute towards meeting the waste reduction targets.

The most significant action highlighted in the English Waste Prevention Plan is the Electrical and Electronic Equipment Sustainability Action Plan (ESAP). This work is being led by the charity the Waste and Resources Action Programme (WRAP) on behalf of UK governments and will help organisations that design, manufacture, sell, repair, re-use and recycle electrical and electronic products to work collaboratively across the product life-cycle. ESAP will stimulate action across five themes: extending product durability through design and customer information; minimising product returns; understanding and influencing consumer behaviour on product durability and reparability; implementing profitable, resilient and resource efficient business models and gaining greater value from re-use and recycling. By November 2014, over 50 organisations from across the UK electrical sector had signed up, including Argos, Beko, Dell, Ifixit, LG, Microsoft, Oxfam and Panasonic (WRAP 2015). This work forms part of WRAP's wider plan for assisting the transition of the UK to a more circular economy (WRAP 2014).

Overall, however, it is fair to say that policy makers in all the UK countries are only just getting to grips with what a circular economy might mean, and the opportunities it presents.

It is not easy to make national policy in this field. As well as trying to influence individual firms and householders to view their waste differently, and struggling to measure flows of materials, implementing a more circular economy might imply seeking to condition the entire economic system in three main ways:

- More centralised encouragement, even direction, of what infrastructure is needed (including infrastructure for collection, sorting and repair/reprocessing of products and materials). Without such an overview and framework to provide some certainties about the likely scale of the circular economy, it may continue to be hard to mobilise private sector investment in the large number of new facilities needed by a genuinely circular economy. None of the country plans suggest going down this route.

- Making secondary materials a more cost effective option than primary. Sometimes market conditions deliver this on their own, but where they don't (often due to the costs of reprocessing or other constraints on supply of secondary materials) there is a case for policy intervention. The 2015 collapse of recovered plastics companies after the fall in the price of oil illustrates this problem. The answer could be through taxes on primary resources, or on non-recyclable products. Alternatively, the incentive could be tax breaks (lowered VAT being the most often mentioned) on products and materials that are more durable or recyclable. 
All these options have been debated by policy makers, but tend to end up in the 'too difficult' box. Plastic carrier bag charges are as far as any of the UK nations have got so far.

- Mandating certain aspects of product design, so that all products are designed for longevity and recovery from the outset. This should change the economics of remanufactured versus new goods, by lowering the costs of remanufacturing. This should also create a new generation of consumer products and, with it, it might be hoped, a change in consumer preferences away from pursuit of newness, towards embracing the durable, the 'pre-loved' and the reclaimed. It would create both supply push and demand pull for reused products and recycled materials. Here, the national plans for Scotland and England signal a cognisance of this possibility in relation to the EU's Ecodesign Directive but in fairly tentative language.

Another complexity for policy makers is that the circular economy debate includes recognition that products and materials have impacts at their point of sourcing, which may create risks for companies and which should be taken into account in their supply chain policies. This is challenging but feasible for companies. For a national government, however, this wider dimension is much harder to handle, as policy instruments that reach beyond national boundaries need careful justification, particularly if they seek to go beyond the internal trading arrangements of the EU. Even EU supranational law making is increasingly under pressure to justify itself to UK, and particularly English, political discourse.

\section{Conclusion}

We have seen that the idea of the circular economy has developed slowly over a period of at least three decades. It builds on the concepts of waste prevention and resource efficiency by showing where the greatest benefits are to be realised, and by emphasising the need to consider the sustainability of the sources of raw materials, as well as their fate. It adds to the development of EU waste and resources policy over the same period by emphasising the economic as well as environmental benefits of durability and recyclability, the need to more firmly link different actors in the economy to achieve comprehensive recovery, and the need to condition product design as the underpinning of the whole system. Progressive businesses are ahead of government in their use of the term, and they have tools available to drive it through their supply chains, but most smaller businesses have yet to fully understand the implications. Leading businesses also draw attention to the framework conditions they need from governments, which include help with collaborative approaches and better data, but also economic intervention in the form of more strategic direction to provide investment certainties, with industries (UK Govt 2013) being the obvious vehicle for this. 
Beyond this, progressive companies often privately signal the need for fiscal intervention, and ways to make secondary resources more cost effective than primary resources, but rarely make these calls in public. The circular economy debate needs to move from being one that augments and energises the recycling debate of the past 30 years, to being about how national economies should be constructed to meet the challenges of the next 30 years. This means involving finance in all its forms: the finance industry (which will provide the capital for circular economy infrastructure); Chief Financial Officers of companies, who will be persuaded of the monetary benefits and new opportunities presented by circular business models; and, most crucially, those in finance ministries who set the framework for businesses through fiscal policy.

Open Access This chapter is distributed under the terms of the Creative Commons Attribution Noncommercial License, which permits any noncommercial use, distribution, and reproduction in any medium, provided the original author(s) and source are credited.

\section{References}

Benton, D. (2015). Circular economy Scotland. London: Green Alliance.

Benton, D., \& Hazell, J. (2013). Resource resilient UK (Circular economy task force). London: Green Alliance.

Defra. (2012). Resource Security Action plan. London: HM Government.

DOENI (2014). The road to zero waste - The waste prevention programme for Northern Ireland. Belfast, Ireland.

EC. (2008). Directive 2008/98/EC of the European Parliament and of the Council of 19th November 2008 on waste and repealing certain directives. E. Commission. Brussels: European Commission.

EC. (2011a). Communication from the Commission to the European Parliament, the Council, the European Economic and Social Committee and the Committee of the Regions. A resourceefficient Europe - Flagship initiative under the Europe 2020 strategy. Brussels: European Commission.

EC. (2011b). The roadmap to a resource efficient Europe. Brussels: European Commission.

EC. (2014a, October 8, 2013). Defining 'critical' raw materials. Retrieved February 24, 2015, from http://ec.europa.eu/enterprise/policies/raw-materials/critical/index_en.htm

EC. (2014b). Integrated product policy. Retrieved February 24, 2015, from http://ec.europa.eu/ environment/ipp/home.htm

EC. (2014c). Communication from the Commission to the European Parliament, the Council, The European Economic and Social Committee and the Committee of the Regions: Towards a circular economy: A zero waste programme for Europe. Brussels: European Commission.

EMF. (2013). Towards the circular economy. Ellen MacArthur Foundation Report No.1.

EREP. (2013). Action for a resource efficient Europe. Brussels: European Commission. Retrieved February 24, 2015, from http://ec.europa.eu/environment/resource_efficiency/re_platform/ index_en.htm

Euroactive. (2015). Ministers want circular economy saved but back commission's better regulation push. Retrieved February 24, 2015, from http://www.euractiv.com/sections/sustainable$\mathrm{dev} /$ ministers-want-circular-economy-saved-backcommissions- better-regulation

Green Alliance. (2015). Circular economy task force. Retrieved February 25, 2015, from http:// www.green-alliance.org.uk/CETF.php

Hill, J. (2014, October). The circular economy: From waste to resource stewardship, part I. Proceedings of the ICE - Waste and Resource Management, 168(1), 3-13. 
HMG. (2013). Prevention is better than cure: The role of waste prevention in moving to a more resource efficiency economy. London: Her Majesty's Government.

NAWRS. (2011). National assembly for Wales Research Service, key issues for the fourth assembly (p. 86). Cardiff.

RSA. (2013). The great recovery - Investigating the role of design in the circular economy (Vol. 1). London: Royal Society of Arts.

Scottish Government. (2013). Safeguarding Scotland's Resources: Blueprint for a more resource efficient and circular economy. Edinburgh: Scottish Government.

UK Govt. (2013). Collection. Industrial Strategy: Government and industry in partnership. Retrieved March 5, 2015, from https://www.gov.uk/government/collections/ industrial-strategy-government-and-industry-in-partnership

Welsh Government. (2013). Towards Zero Waste: One wales, one planet. Cardiff: Welsh Government.

WRAP. (2014). WRAP's vision for the UK circular economy to 2020. Retrieved February 24, 2015, from http://www.wrap.org.uk/content/wraps-vision-uk-circular-economy-2020

WRAP. (2015). Electronic and Electricals Sustainability Action Plan (ESAP). Retrieved February 24, 2015, from http://www.wrap.org.uk/content/esap-generating-value-business-through-sustainability 